\title{
A Developed Framework Of Mediating Role Of Inbound Innovation Strategy Between BOS And Innovation Performance
}

\author{
Muhammad Shafiq, Rosmaini Tasmin, Muhammad Imran Qureshi
}

\begin{abstract}
Innovation research has got a very significant value in modern research. In contemporary galvanized world, supremacy of new innovation strategies has taken over older strategies. Inbound and outbound innovation strategies have moved from resources based closed innovations within the organization to relation based innovations via interaction with outside world of organizations and customers. There have been research on the relationship of these open innovation strategies with organizational performance and innovation performance. But there was a great need of the empirical research on the impacts these strategies make on innovation performance in Malaysian manufacturing industries. As Malaysia is on slide on world innovation index from 31st to 37th in last five years, an alarm for academics, researchers, industry and government. This endeavor meets that objective. After introduction of the main constructs, a detailed literature review is presented. And a research framework is designed on the basis of the literature. AN updated model of innovation is proposed for BOS and innovation performance.
\end{abstract}

This is an empirical study so the hypothesis are formulated. It is a quantitative research study so data was collected from all over the Malaysian manufacturing and services sector to have a detailed view of the industry. Appropriate different statistical tests are applied to display results considering the requirements of industry, academia and other stake holders.

In the end results are presented, and the conclusion is provided for the benefits of Malaysian industries and government. Some insights in the future research area are also provided for the researchers.

Keywords: Inbound Innovation, Innovation Performance, Blue ocean strategy

\section{INTRODUCTION}

Growth of organizations are attached to innovation (Terziovski, 2002). Many scholars have discussed stratgeies of innovation (Dasgupta \& Sanyal, 2009; Vinayan, Jayashree, \& Marthandan, 2012) and (Matzler, Bailom, Friedrich von den Eichen, \& Kohler, 2013). Open innovation strategy is well known as a collaborative strategy and got much of the attention in recent past. Inbound open innovation is attractive and necessary to study in Malaysian industry in relation to innovation performance and organizational performance. It raises the research enquiry about 'mediating role of inbound innovation between the

Revised Manuscript Received on April 19, 2019.

Muhammad Shafiq, Assistant Professor, Department of Management Sciences, Muhammad Ali Jinnah University, Karachi Pakistan

Rosmaini Tasmin, Associate Professor, Faculty of Technology Management and Business, Universiti Tun Hussein Onn Malaysia, Johor Malaysia.

Muhammad Imran Qureshi, Senior Lecturer, Faculty of technology Management and Technoprenurship, Universiti Teknikal Melaaca, Malaysia.. relationships of Blue ocean strategy and innovation performance.

\section{LITERATURE REVIEW}

This section has literature review of the variables and their relationship.

\subsection{Open Innovation Strategies}

Innovation is very important in contemporary business research. Success and competitive advantage depends on it for business organizations. According to (Johannessen, Olsen, \& Lumpkin, 2001) market share raises because of it Firms have to innovate systematically with multiple strategies to have competitive edge (Muhammad, Rosmaini, \& Mehwish, 2017; M Shafiq \& Tasmin, 2016; Muhammad Shafiq, Tasmin, Takala, Qureshi, \& Rashid, 2017). (Garcia \& Calantone, 2002) beautifully discussed about innovation strategies. Strategic growth is achieved by keeping a balance in the utility of capabilities and resources.

Open innovation has been frequently examined in literature during last decade (Chesbrough, Vanhaverbeke, \& West, 2006; Christensen, Olesen, \& Kjær, 2005; West \& Gallagher, 2006). Organizations managing relationships with other organizations have to strategize their innovation. Involvement of various parties require special innovation protocols and relationships. According to (Laursen \& Salter, 2006), Open innovation is occasionally associated with the various outside sources for innovation, while (Henkel, 2006) and others define it as disclosing previously covered ideas of organization. Inbound and outbound open innovation are two forms of open innovation. These both open innovation strategies are taken in this study. Inbound Open Innovation is the dimension of open innovation which look for acquiring expertise and skills of the other organization for improving organization's own innovation capabilities. Outbound Open Innovation is the dimension of open innovation focus on financial gains through collaborations with other organizations as (Chiaroni, Chiesa, \& Frattini, 2011) explain.

Technological leadership and internationalization of activities explain open innovation. Organization must possess different competencies especially in research and technology for its success. Monetary and commercial risks are part due to high outflows and partnerships of collaborations with an external organization as explained by (Dodgson, Gann, \& Salter, 2005). Roles, responsibilities, 
partner selection, goals and partner selection of this process need efficient control and management.

\subsection{Blue Ocean Strategy}

Developing and sustaining competitive edge through different strategies, for example; Miles and Snow's strategy approach, Porter's differentiation and cost, the resourcebased approach of tangible and non-tangible assets, dynamic capabilities (Teece \& Pisano, 1994) and Blue Ocean Strategy of Kim and Mauborgne (2005) have been the focus of the organizations (Grant, 2016). These have helped organizations to a great extent to compete, though in today's difficult business environment where diversification and innovation are very important for growth (Parnell, 2010). Strategic thinking has revolutionized the business and scholars deserve appreciation (Hitt, Ireland, \& Hoskisson, 2012).

The strategy has been developed through centuries to reach the modern organizational stage, as Porter (1996) said that organizational effectiveness is not a strategy. According to Mintzberg (1978), the pattern of decisions for the future of firm was defined as a strategy. Porter (1980) produced his strategy for competitive advantage based on differentiation and cost. Before him, Miles, Snow, Meyer, and Coleman (1978) presented the (prosperous, analyzer, defender, and reactor) strategies for firms growth in competition. Kim \& Mauborgne (2005) shook the strategic research world with the phenomena of making the competition irrelevant. They presented the 'The Blue Ocean Strategy' which has "a specific constant configuration of strategic rationale behind the creation of 'new markets and industries' to create demand rather fighting" (Kim \& Mauborgne, 2005). According to them, competition is irrelevant, and organizations have to swim out of red bloody oceans of competition. There have been many research, appreciation, and critique around the world on Blue Ocean strategy including (Butler, 2008; Lindič, Bavdaž, \& Kovačič, 2012; Rebón, Ocariz, Gerrikagoitia, \& Alzua-Sorzabal, 2015; Wubben, Düsseldorf, \& Batterink, 2012). The big part of the debate revolved around the differences between Red ocean strategies of the competition, and blue ocean strategy of uncontested industries and markets. Blue Ocean strategy created enormous interest among researchers.

Blue Ocean strategy is "a consistent pattern of strategic thinking behind the creation of new markets and industries where demand is created rather than fought for and the rule of competition is irrelevant". BOS has five constructs, "Creating New Uncontested Market Space, Making Competition Irrelevant, Creating and Capturing New Demand, Achieving Differentiation and Cost, Breaking Value Cost Tradeoff" (Kim \& Mauborgne, 2005; Kim \& Mauborgne, 2014). These five constructs of BOS are independent variables of the study, representing BOS.

Uncontested market space creation is the foremost concept of BOS, this is important for an organization to move out of existing market crowd, and create a new space to attract customers. Uncontested market space creation is the foremost concept of BOS, this is important for an organization to move out of existing market crowd, and create a new space to attract customers. It is the strategy in which an organization spaces the customer's requirements as the focus of its principles and policies and centers on customers' needs and learning about them (Kim \& Mauborgne, 2014; Song, Wei, \& Wang, 2015).

Making competition irrelevant is the $2^{\text {nd }}$ construct of BOS, as organizations who swim out of the competition to open blue sea are able to get a competitive advantage as competition takes away energies and innovation capability. Competition is the hallmark of red oceans as contemporary business work is crowded as the bloody red ocean (Kim \& Mauborgne, 2014).

'Create and capture New Demand' is another construct of BOS where organizations focus to create new demand, instead of sharing the existing demand. This is very important as organizations do not focus only on existing demand of the market but create new products and services to attract new customers. It helps organization to avoid competition and attract new customers.

'Breaking the Value-Cost Tradeoff' is an important construct of Blue Ocean Strategy as organizations used to increase cost when creating new value. BOS makes organizations able to break this tradeoff and achieve both at the same time. Organizations create values to intact old customers and attract new customers but the provision of value enhances cost for both organization and customers. This construct of BOS helps the organization to create a value which has worth of the cost, and customers attract to pay for it, as cost should not be very high.

The fifth and the last attribute of BOS is to 'Achieve differentiation and cost'. Contrary to Michael porter strategy of differentiation or cost, BOS is 'differentiation' 'and' 'cost' strategy, not only 'differentiation' or 'cost' strategy. This feature of BOS pulls customers towards organizations and helps it to create value for both customers and business. Historically organizations create differentiation but it increases cost but the organization practicing Blue Ocean Strategy though provides new features but at a cost which is satisfactory for customer.

\subsection{Innovation performance}

As stated by (Jiang \& Li, 2009), activities of innovation, for example new products, new services and number of patents define the innovation performance of an organization. Innovation performance displays contribution of product and process innovations to firm performance. It is an imperative way to give competitive advantage to organizations. According to (Lokshin, Van Gils, \& Bauer, 2009), it is identified as exciting capacity of an organization to cultivate new products and services. As (Teece, Pisano, \& Shuen, 1997) explained that, scholars have acknowledged that organizations achieve competitive advantage because of the ability to renew, assimilate and increase present capabilities and continuously develop new capacities. Product innovation is an important process via which organizations transform and establish competencies that are central for staying competitive within the speedy changing business situation (Lokshin et al., 2009). 
Innovation is multi-dimensional concept involving several types and strategies (Muhammad Shafiq et al., 2017). Product innovation is defined as the development or use of new components, features and technologies to produce new products. Product innovation has direct effect on firms' business performance (Rauch, Wiklund, Lumpkin, $\&$ Frese, 2009). Process innovation is defined as the improvement to production processes technologies required to produce a product and it is mostly internal of the organization (Reichstein \& Salter, 2006) .

(Johannessen et al., 2001) scale, was used to measure innovation performance which has six dimensions of new products, new services, new methods of production, Opening new markets, new sources of supply, new ways of organizing

\subsection{Mediating Role of Inbound Open Innovation} Strategies between the BOS and Innovation Performance

As mentioned in (M Shafiq \& Tasmin, 2016; Terziovski, 2002) works, relationship of strategy with innovation is well discussed. As non-innovative and innovative firms have different strategies and capabilities as mentioned by (Tabak \& Barr, 1999)and quoted by (Karabulut, 2015).

As mentioned by (Karabulut, 2015), in these competitive environments, organizations has to adopt different schemes and strategies to innovate differently to make and sustain a position. According to (Dasgupta \& Sanyal, 2009), now sustainable competitive advantage will originate from cooperated work and collaborations of organizations. (Iansiti \& Levien, 2004), warn that aloof organization will not succeed in future, organizations have to use collaborative strategy to mutually produce new products. This study focuses the innovation strategies of inbound and innovation performance. Outsourcing decisions has also taken a significant position in the strategizing of organizations, as mentioned by (McIvor \& Humphreys, 2000), new innovations leads decision makers to these avenues (Fine et al., 2002). As acquiring a component or technology or developing it from scratch with the boundaries of the organization is important (Mayers \& Brenner, 1995). (Johannessen et al., 2001), discuss the importance of innovation with innovation performance. They suggest to explore the internal and external factors of innovation. Do industry relate to issues such as the newness or radicalness of an innovation? And many related questions. Innovation gets speed up by information availability and technological mergers. Organization gets open up with the help of open organization (Gobbo \& Olsson, 2010). This has attracted many scholars towards open innovation strategy. According to (Prajogo \& Ahmed, 2007), there is less literature available on the benefits of each of the innovation strategy. As Matthias et al (2012), mentioned that in future, research should be conducted to analyze how open-source innovation can best be operationalized to enhance the innovation performance of firms. (Leminen et al., 2016) also stress the need to explore the relationship between open innovation strategy and innovation performance.
In light of all above discussions in introduction and literature view, below is displayed the model of the study.

\subsection{Research Model}

Blue Ocean Strategies

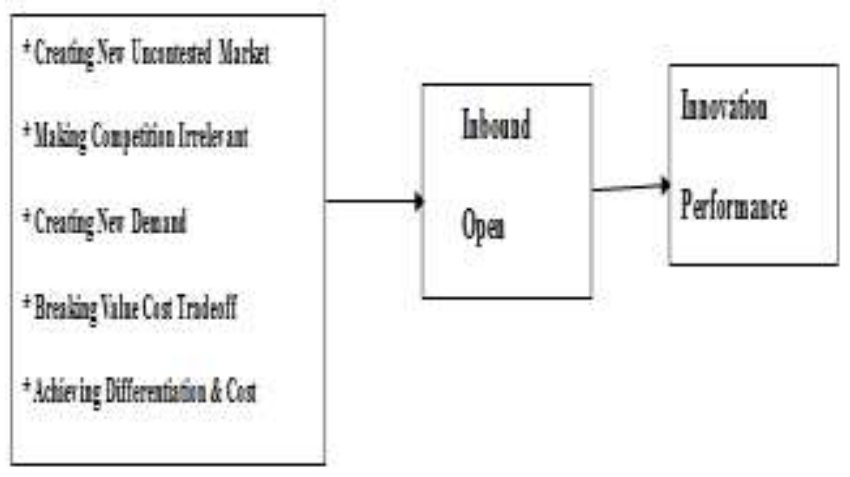

\subsection{Hypothesis of the study}

In the light of the above discussion, following hypothesis are formulated.

$\mathrm{H}$ : Inbound open innovation strategy mediates relationship of BOS and innovation performance.

Ha: Inbound open innovation strategy mediates relationship between Creating New Uncontested Market and innovation performance.

$\mathrm{Hb}$ : Inbound open innovation strategy mediates relationship between Making competition irrelevant and innovation performance.

Hc: Inbound open innovation strategy mediates relationship between creating new demand and innovation performance.

Hd: Inbound open innovation strategy mediates relationship between Breaking value-cost tradeoff and innovation performance.

He: Inbound open innovation strategy mediates relationship between achieving differentiation and cost and innovation performance.

\section{METHODOLOGY}

As explained earlier, this is an empirical study which is performed quantitatively by performing appropriate statistical tests. Data was collected used google forms by sending emails to all manufacturing organizations using FMM2017. Response rate was very good. The study is performed on the 270 responses of the study. PLS3 was used for data analysis as Preacher \& Hayes (2008) was used for mediation analysis, and bootstrapping was applied.

\section{ANALYSIS AND RESULTS}

The figure below presents the measurement model of the study having the exogenous independent variables of BOS five constructs, and endogenous mediating variable is inbound innovation while endogenous dependent variable is innovation performance. 


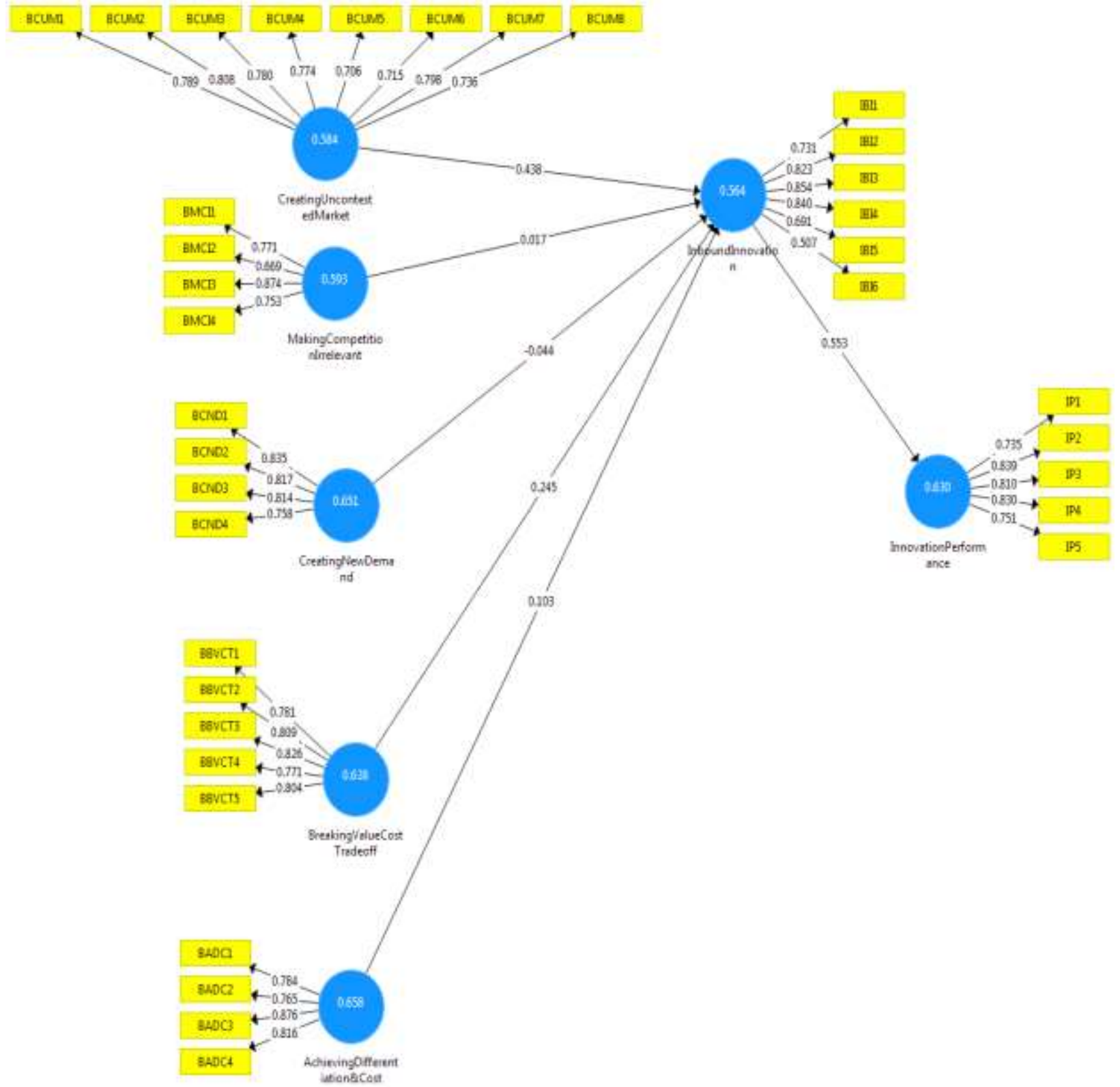

Results confirm that there is no multicollinearity issue in the data as tolerance and VIF values are well within the range, while construct and discriminant validities are also conformed through AVE which is above 0.5 and HTMT values which are well below to 0.85 .

In this study, the 'Inbound open innovation' and 'Outbound Open Innovation' were identified as mediator on the relationship between Blue ocean strategy constructs (Creating New Uncontested Market, Creating New Demand, Making Competition Irrelevant, Achieving Differentiation and Cost, and Breaking Value-Cost Trade-off) and innovation performance. Therefore, two main and five subhypotheses were formulated for each relationship of Inbound open innovation and Outbound Open Innovation. Table shows the result of mediation analysis respectively.
Hypothesis six of the study claims that 'Inbound open innovation' mediates the relationship between the BOS and the innovation performance. Further, this hypothesis was divided into five indirect paths. This study used (Preacher \& Hayes, 2008) method to test the mediation. For this purpose, this study used two-step approaches. At first step, all direct relationships were estimated in two ways, first direct relationships without mediator and second direct relationship with a mediator. At the second stage, all indirect effects have been calculated and their significance through the bootstrapping was calculated. It was found that three of the five indirect paths were significant. This indicates the existence of mediation effect. Figure 4.7 indicates the inbound mediation analysis of the study. 


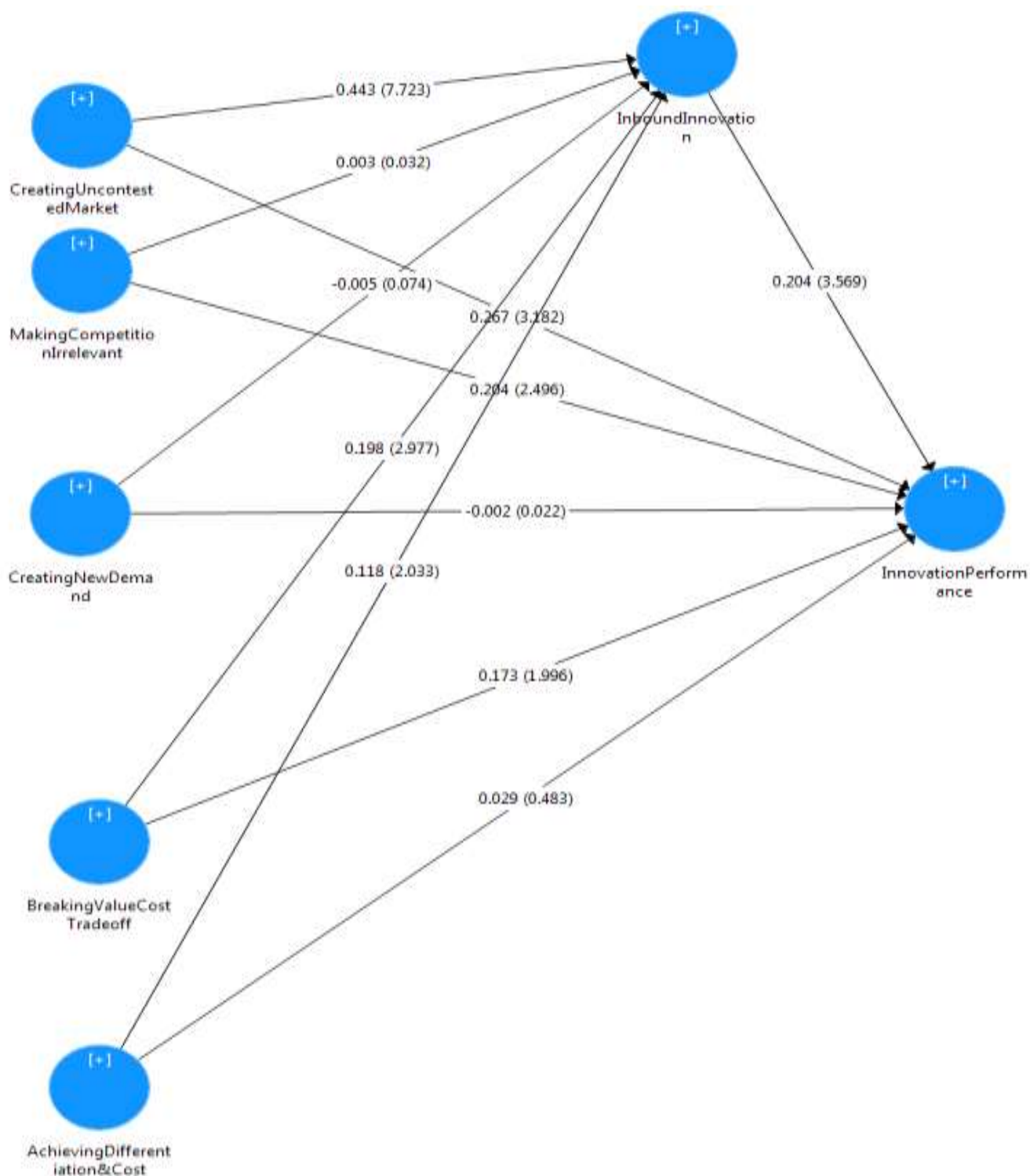

AchievingDifferent

innovation performance was $T$ value of 3.515 with a $P$ value

\section{Mediation Analysis of Inbound Innovation}

Hypothesis Ha stated: 'Inbound open innovation mediates the relationship between 'Creating New Uncontested Market' and innovation performance'. The results indicated that the path coefficient of the indirect path for mediation effect of 'Inbound open innovation' in the relationship between 'Creating New Uncontested Market' and 'innovation performance' was reported as 0.099. To test the significance, bootstrapping procedure was adapted with 5000 irritations. T value for the indirect path Creating New Uncontested Market $\rightarrow$ Inbound open innovation $\rightarrow$ of 0.000 . This value is higher than 1.96 which indicates the significance of the mediation effect, thus, hypothesis Ha has been accepted.

Hypothesis $\mathrm{Hb}$ states that: Inbound open innovation mediates the relationship between 'Creating New Demand' and innovation performance. The results indicate that the path coefficient of indirect path Creating New Demand $\rightarrow$ inbound open innovation $\rightarrow$ innovation Performance was reported as -0.001 with $\mathrm{T}$ value 0.053 and $\mathrm{P}$-value 0.479 . This indicates the non-significance of the mediation effect. Thus, hypothesis $\mathrm{Hb}$ was rejected. 
International Conference on Recents Advancements in Engineering and Technology (ICRAET-18) |15th and 16th March 2019|Siddhartha Institute of Technology \& Sciences, Telangana, India.

Table .The results of mediation effect of inbound open innovation

\begin{tabular}{|l|l|l|l|l|}
\hline Paths & Coefficients & $\begin{array}{l}\text { Standard } \\
\text { Deviation } \\
(\text { STDEV })\end{array}$ & $\begin{array}{l}\text { T Statistics } \\
(\mid \mathrm{O} / \mathrm{STDEV})\end{array}$ & P Values \\
\hline $\begin{array}{l}\text { Breaking Value Cost Tradeoff -> Innovation } \\
\text { Performance }\end{array}$ & 0.044 & 0.018 & 2.411 & 0.008 \\
\hline Creating New Demand -> Innovation Performance & -0.001 & 0.017 & 0.053 & 0.479 \\
\hline $\begin{array}{l}\text { Creating Uncontested Market -> Innovation } \\
\text { Performance }\end{array}$ & 0.099 & 0.028 & 3.515 & 0.000 \\
\hline $\begin{array}{l}\text { Differentiation \& Cost -> Innovation } \\
\text { Performance }\end{array}$ & 0.036 & 0.014 & 2.124 & 0.012 \\
\hline $\begin{array}{l}\text { Making Competition Irrelevant -> Innovation } \\
\text { Performance }\end{array}$ & -0.001 & 0.019 & 0.044 & 0.483 \\
\hline
\end{tabular}

Hypothesis Hc states: Inbound open innovation mediates the relationship between 'Making Competition Irrelevant' and innovation performance. Results indicated that the path coefficient of the indirect path 'Making Competition Irrelevant' $\rightarrow$ Inbound Open Innovation $\rightarrow$ Innovation Performance was reported as -0.001. To test the significance, bootstrapping procedure was adapted with 5000 irritations. $\mathrm{T}$ value for the indirect path 'Making Competition Irrelevant' $\rightarrow$ Inbound Open Innovation $\rightarrow$ Innovation Performance was 0.044 , this value is lower than 1.96 and $\mathrm{p}$-value was 0.483 indicating the non-significance if the mediation effect. Thus hypothesis Hc was rejected.

Hypothesis Hd states: Inbound open innovation mediates the relationship between 'Achieving Differentiation and Cost' and 'innovation performance'. Results indicated that the path coefficient of the indirect path 'Achieving Differentiation and Cost' $\rightarrow$ Inbound open Innovation $\rightarrow$ Innovation Performance was reported as 0.036. To test the significance, bootstrapping procedure was adapted with 5000 irritations. $\mathrm{T}$ value for the indirect path 'Achieving Differentiation and Cost' $\rightarrow$ Inbound open Innovation $\rightarrow$ Innovation Performance was 2.121, this value is higher than 1.96 and $\mathrm{P}$-value was 0.012 indicating the significance of the mediation effect, thus hypothesis Hd was accepted.

Hypothesis He states: Inbound open innovation mediates the relationship between 'Breaking Value-Cost Trade-off' and innovation performance. Results indicated that the path coefficient of indirect path 'Breaking Value-Cost Trade-off' $\rightarrow$ Open Innovation $\rightarrow$ Innovation Performance was reported as 0.044 . To test the significance, bootstrapping procedure was adapted with 5000 irritations. $\mathrm{T}$ value for the indirect path 'Breaking Value-Cost Trade-off' $\rightarrow$ Inbound Open Innovation $\rightarrow$ Innovation Performance was 2.411 , this value is higher than 1.96 and p-value was 0.008 indicating the significance of the mediation effect, thus hypothesis He was accepted.

New Developed Model of BOS, Inbound Innovation and Innovation Performance

\section{Blue Ocean Strategies}

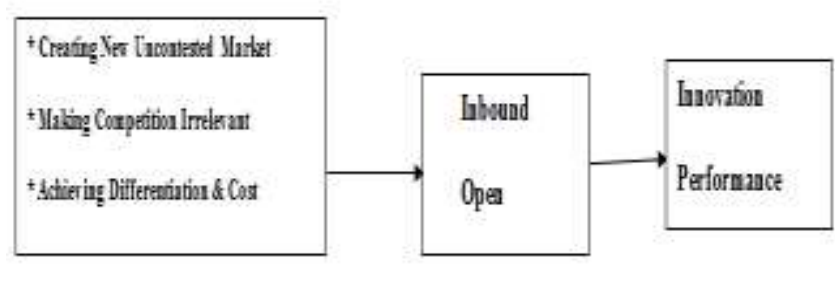

\section{CONCLUSION}

Results of the paper clearly show that inbound open innovation strategies; mediate the three of the BOS constructs, while it does not mediate the breaking value cost tradeoff and creating new demand aspect. It shows that organizations collaborate with other organizations for enhancing their capabilities and skills for innovation are more successful towards innovation performance of the organization. This is very important research and answers important questions for Malaysian industries as inbound open innovation is very important for innovation performance, an important element of competitive advantage. Moreover, this research gives a blueprint for the organizations practicing Blue ocean strategy, which of the BOS dimensions will contribute to innovation performance in presence of inbound innovation, which is more focused to collaborate to generate internal capabilities.

\subsection{Future Work}

This results thought very significant and important for the Malaysian industries, and contributes towards the dynamic capability theory in study of organization's collaborations for the better innovation performance. There have been previous research by authors (Shafiq \& Tasmin, 2016) about the relationships of business strategies with open and close innovations. Authors have already published the research of open innovation strategies as mediators between relationships of different conventional (Muhammad et al., 2017) and modern business strategies (Muhammad Shafiq et al., 2017) with innovation and organizational performances 
respectively, and some work is in publication. Moreover, in future, the mediating role of inbound open innovation should be examined between the relationship of BOS and innovation types of radical, incremental and nondestructive innovations respectively. Moreover, this research is only limited to Malaysian industries which can be spread to other countries as well.

\section{ACKNOWLEDGEMENT}

"This paper is sponsored by the Research Management Center (RMC) of Universiti Tun Hussein Onn Malaysia (UTHM), Johor Malaysia"

\section{REFERENCES}

1. Chesbrough, H., Vanhaverbeke, W., \& West, J. (2006). Open innovation: Researching a new paradigm: Oxford University Press on Demand.

2. Chiaroni, D., Chiesa, V., \& Frattini, F. (2011). The Open Innovation Journey: How firms dynamically implement the emerging innovation management paradigm. Technovation, 31(1), 34-43.

3. Christensen, J. F., Olesen, M. H., \& Kjær, J. S. (2005). The industrial dynamics of Open Innovation-Evidence from the transformation of consumer electronics. Research policy, 34(10), 1533-1549.

4. Cohen, J. (1988). Statistical power analysis for the behavioral sciences. Hilsdale. NJ: Lawrence Earlbaum Associates, 2.

5. Dasgupta, S., \& Sanyal, D. (2009). Bridge to the future: connect your strategies in an interconnected world. Foresight, 11(1), 81-93.

6. Dodgson, M., Gann, D., \& Salter, A. J. (2005). Think, play, do: Technology, innovation, and organization: Oxford University Press on Demand.

7. Garcia, R., \& Calantone, R. (2002). A critical look at technological innovation typology and innovativeness terminology: a literature review. Journal of product innovation management, 19(2), 110-132.

8. Gobbo, J. A., \& Olsson, A. (2010). The transformation between exploration and exploitation applied to inventors of packaging innovations. Technovation, 30(5), 322-331.

9. Henkel, J. (2006). Selective revealing in open innovation processes: The case of embedded Linux. Research policy, 35(7), 953-969.

10. Iansiti, M., \& Levien, R. (2004). The keystone advantage: what the new dynamics of business ecosystems mean for strategy, innovation, and sustainability: Harvard Business Press.

11. Jiang, X., \& Li, Y. (2009). An empirical investigation of knowledge management and innovative performance: The case of alliances. Research policy, 38(2), 358-368.

12. Johannessen, J.-A., Olsen, B., \& Lumpkin, G. T. (2001). Innovation as newness: what is new, how new, and new to whom? European Journal of innovation management, 4(1), 20-31.

13. Karabulut, A. T. (2015). Effects of Innovation Strategy on Firm Performance: A Study Conducted on Manufacturing Firms in Turkey. Procedia-Social and Behavioral Sciences, 195, 1338-1347.

14. Laursen, K., \& Salter, A. (2006). Open for innovation: the role of openness in explaining innovation performance among UK manufacturing firms. Strategic management journal, 27(2), 131-150.

15. Leminen, S., Leminen, S., Nyström, A.-G., Nyström, A.G., Westerlund, M., Westerlund, M., . . Kortelainen, M. J. (2016). The effect of network structure on radical innovation in living labs. Journal of Business \& Industrial Marketing, 31(6), 743-757.
16. Lokshin, B., Van Gils, A., \& Bauer, E. (2009). Crafting firm competencies to improve innovative performance. European Management Journal, 27(3), 187-196.

17. Matzler, K., Bailom, F., Friedrich von den Eichen, S., \& Kohler, T. (2013). Business model innovation: coffee triumphs for Nespresso. Journal of Business Strategy, 34(2), 30-37.

18. Mayers, A., \& Brenner, Y. (1995). "Make or buy": the potential subversion of corporate strategy-the case of Philips. International Journal of Social Economics, 22(4), 4-11.

19. McIvor, R. T., \& Humphreys, P. K. (2000). A case-based reasoning approach to the make or buy decision. Integrated Manufacturing Systems, 11(5), 295-310.

20. Muhammad, S., Rosmaini, T., \& Mehwish, R. (2017). Mediating Role of Innovation Strategy Between Porter's Red Ocean Strategy and Innovative Performance. Advanced Science Letters, 23(9), 9239-9242.

21. Nunnally, J. (1978). Psychometric methods: New York: McGraw-Hill.

22. Prajogo, D. I., \& Ahmed, P. K. (2007). The relationships between quality, innovation and business performance: An empirical study. International Journal of Business Performance Management, 9(4), 380-405.

23. Rauch, A., Wiklund, J., Lumpkin, G. T., \& Frese, M (2009). Entrepreneurial orientation and business performance: An assessment of past research and suggestions for the future. Entrepreneurship theory and practice, 33(3), 761-787.

24. Reichstein, T., \& Salter, A. (2006). Investigating the sources of process innovation among UK manufacturing firms. Industrial and Corporate change, 15(4), 653-682.

25. Shafiq, M., \& Tasmin, R. (2016). Linking Business Strategy with Organizational Innovation. INNOVATION AND MANAGEMENT.

26. Shafiq, M., Tasmin, R., Takala, J., Qureshi, M. I., \& Rashid, M. (2017). RELATIONSHIP OF BLUE OCEAN STRATEGY AND INNOVATION PERFORMANCE, AN EMPIRICAL STUDY.

27. Tabak, F., \& Barr, S. H. (1999). Propensity to adopt technological innovations: the impact of personal characteristics and organizational context. Journal of Engineering and Technology Management, 16(3), 247270 .

28. Teece, D. J., Pisano, G., \& Shuen, A. (1997). Dynamic capabilities and strategic management. Strategic management journal, 509-533.

29. Terziovski, M. (2002). Achieving performance excellence through an integrated strategy of radical innovation and continuous improvement. Measuring Business Excellence, 6(2), 5-14

30. Vinayan, G., Jayashree, S., \& Marthandan, G. (2012). Critical success factors of sustainable competitive advantage: A study in Malaysian manufacturing industries. international journal of business and management, 7(22), 29.

31. West, J., \& Gallagher, S. (2006). Challenges of open innovation: the paradox of firm investment in opensource software. R\&d Management, 36(3), 319-331. 